\title{
Low Level of Innovativeness and the Middle Income Trap - Polish Case Study
}

\author{
Kamil Pruchnik, Jerzy Toborowicz ${ }^{* *}$
}

\begin{abstract}
The aim of this paper was to verify whether Poland managed to avoid or still might fall into the middle income trap. The paper provides a literature overview concerning the middle income trap. Though there are diverging interpretations of the notion of middle income trap, common conclusions of economists emphasize the importance of innovation-based transformation of economies as a way of avoiding the trap. Further, the paper overviews literature concerning public policies which support this much-needed transformation. We conclude that countries such as Finland, Israel or the USA implemented well-designed top-down economic strategies, which promoted the development of innovations and established effective implementation agencies. Exceptions from this model are some resource rich countries, which managed to avoid the middle income trap without the implementation of such policies, but these countries face in most cases the danger of falling into another trap, called 'the Dutch disease'. In a subsequent part of the article, we attempt to apply the middle income trap concept to Poland and conclude that it is not possible to clearly state whether Poland avoided the trap or not. This is followed up by a literature-based review of the most common obstacles to innovativeness in Poland. The current growth engines might not be sufficient to ensure economic growth fast enough to speed up the catching up with the most developed countries.

Keywords: innovation, economy, strategy, social capital, institutions, human capital, infrastructure, middle income trap.
\end{abstract}

\section{INTRODUCTION}

Undoubtedly, Poland has made a remarkable progress in terms of economic development over the last 25 years. We can identify two major engines powering its growth. The first one were free-market reforms implemented at the beginning of the 1990s. Transformation of the economy and creation of foundations for its further development (by liberalizing, privatizing and

\footnotetext{
* Kamil Pruchnik, Ph.D. student at Warsaw School of Economics, 15B Polna Street, 05-500 Mysiadło, Poland, kamilpruchnik@gmail.com

** Jerzy Toborowicz, Ph.D. student at Kozminski University, 19/19 Kasprowicza Street, 01-859 Warsaw, Poland, jerzy. toborowicz@gmail.com
} 
stabilizing it), as well as radical abandonment of the former political system, freed the economic potential of entrepreneurial Poles, suppressed for decades (Winiecki, 2012). The other growth engine was Poland's accession to the European Union (hereinafter referred to as EU). The World Bank economists (Gill and Raisner, 2012) named the EU 'the convergence machine', emphasizing how the strong process of integration with the community supports the convergence process in Central and Eastern European countries (hereinafter referred to as CEE). Simultaneously to the advancing economic integration we observed the tightening and harmonizing of the Polish law, institutions and infrastructure with European requirements. All these changes accelerated the process of transformation in Poland, acting in the economic, social and political dimensions at the same time (Piątkowski, 2013).

However, the scientific research shows that periods of accelerating growth lasting 20-30 years are not necessarily permanent. Some countries, after decades of dynamic catching up, 'used up' their primitive growth engines such a cheap labor or productivity growth powered by import of know-how and innovation from abroad. As a result, they 'get stuck' among countries which are poorer and compete by low prices, e.g. China, and countries which are richer and compete by their innovations, e.g. USA. This phenomenon of slowing down or stopping the process of catching up with the richest countries has been called 'the middle income trap' by the World Bank economists. Thus, a questions arises - is the Polish economic growth powered by forces that will enable it to avoid the middle income trap? Or has Poland managed to avoid the trap already? If not, what is the potential danger for falling into the trap? In this paper, we try to answer these questions.

\section{RESEARCH METHOD}

This paper is based on literature review. In order to determine whether Poland has already avoided the middle income trap or might fall into it in the future, it is essential to first understand what the middle income trap really is. Thus, we start our paper by providing literature review on what the middle income trap is and how countries managed to avoid it. We look at academic research as well as at research conducted by international institutions such as the World Bank or the International Monetary Fund. We find out that there is no universal definition of middle income trap and research offers different thresholds for it. However, researchers conclude that one of the main reasons some countries managed to avoid it is the high level of innovativeness of their economies.

Next we try to determine the possible cause for innovative growth of selected countries. We concentrate our literature review on Finland, Israel

Perspectives on Innovations Management - Environmental, Social and Public Sector Innovations, Krzysztof Klincewicz, Anna Ujwary-Gil (Eds.) 
and the USA as these counties avoided the middle income trap according to interpretations of middle income trap provided in the previous section. The literature review suggests that one of the possible explanations of their innovative growth is the implementation of a top-down strategy aimed at supporting innovative growth, which was carried out by public agencies responsible for it.

In the next section we use the various interpretations of the middle income trap and try to see whether Poland managed to avoid it or fall into it. It seems that experts are divided on this subject. However, regardless of how we define the middle income trap thresholds, what is more important is whether the Polish economic growth is powered by innovations or more primitive growth engines. In order to determine this, we provide literature review of most recognizable rankings of innovation and conclude that Poland is not an innovative economy. Thus, there is a risk of a substantial slowdown in economic growth in the medium term. This is supported by research form Poland and abroad. We finish this section with a review of the most common obstacles for innovations in Poland.

\section{UNDERSTANDING THE MIDDLE INCOME TRAP}

The middle income trap is a relatively new phenomenon in economics. The term was coined by Indermit Gill in 2007 and presented in a World Bank report entitled "An East Asian Renaissance". He found that out of the countries that were middle-income in 1960, almost three-fourths remained middle-income or regressed to low-income by 2007 - hence the term "middle income trap". Since 2007, the term has become very popular among economists and policy makers.

There are many different interpretations of this phenomenon among researchers. We decided to present four most frequently cited papers on the subject internationally and one Polish paper that was published by the Institute for Structural Research (Polish name: Instytut Badań Strukturalnych).

We start with an academic study conducted by Eichengreen, Park and Shin (2012), which might be the most comprehensive one on the matter. In their paper, the team identifies the thresholds for the middle income trap at the level of GDP per capita at 15000 USD (2005 USD PPP). They conclude that countries that fall into the middle income trap have a set of common characteristics such as: unfavorable demographics, undervalued exchange rate, low share of economically active population with higher education and low share of high-tech sectors in GDP and exports. They argue that countries that avoided the trap had a high level of productivity growth and innovation. 


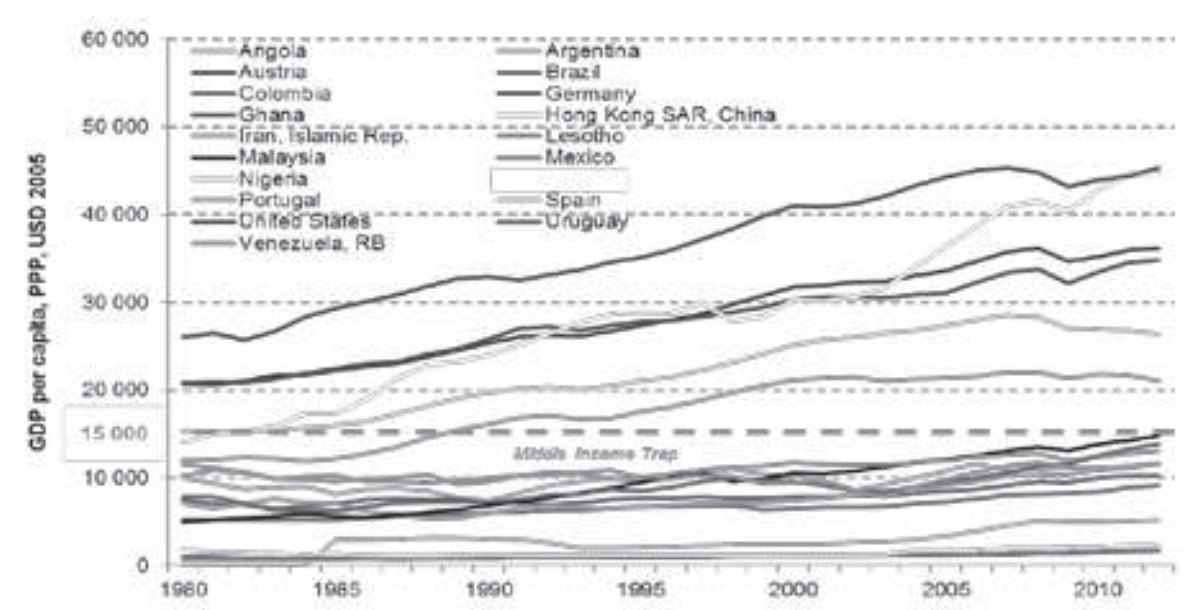

Figure 1. Middle income trap - interpretation by Eichengreen et al. (2012) and Ayiar et al. (2013)

Note: for each of the following graphics illustrating different concepts of middle income trap we updated the original charts form the articles to the newest available data (from 10.2014).

Source: own elaboration based on World Development Indicators (World Bank, 2014).

Another study that we would like to introduce is a paper published by the International Monetary Fund. Ayiar, Duval, Puy, Wu and Zhang (2013) set their threshold for the middle income trap at the level of 15000 USD of GDP per capita (2005 USD PPP). They point out that what increases the probability of a country to fall into the trap are: poor quality of the legal system, poor enforcement of contracts and property rights, excessive growth of the public sector, over-regulation and unfavorable demographics. Again, the productivity growth as well as innovations increase the probability of avoiding the middle income trap.

Further academic research was conducted by Felipe, Abdon and Krumar (2012). According to their research, countries that fell into the trap typically had low levels of diversification of the economy, low levels of human capital, weak legal and institutional set-ups and low levels of diversification of exports, with exports dominated by low-processed goods. They set up the threshold for the middle income trap at the level of 11500 USD GDP per capita (1990 USD PPP). Similarly to Eichengreen et al. (2012) and Ayiar et al. (2013), they pointed out that productivity growth and innovations help countries avoid the trap.

Perspectives on Innovations Management - Environmental, Social and Public Sector Innovations, Krzysztof Klincewicz, Anna Ujwary-Gil (Eds.) 


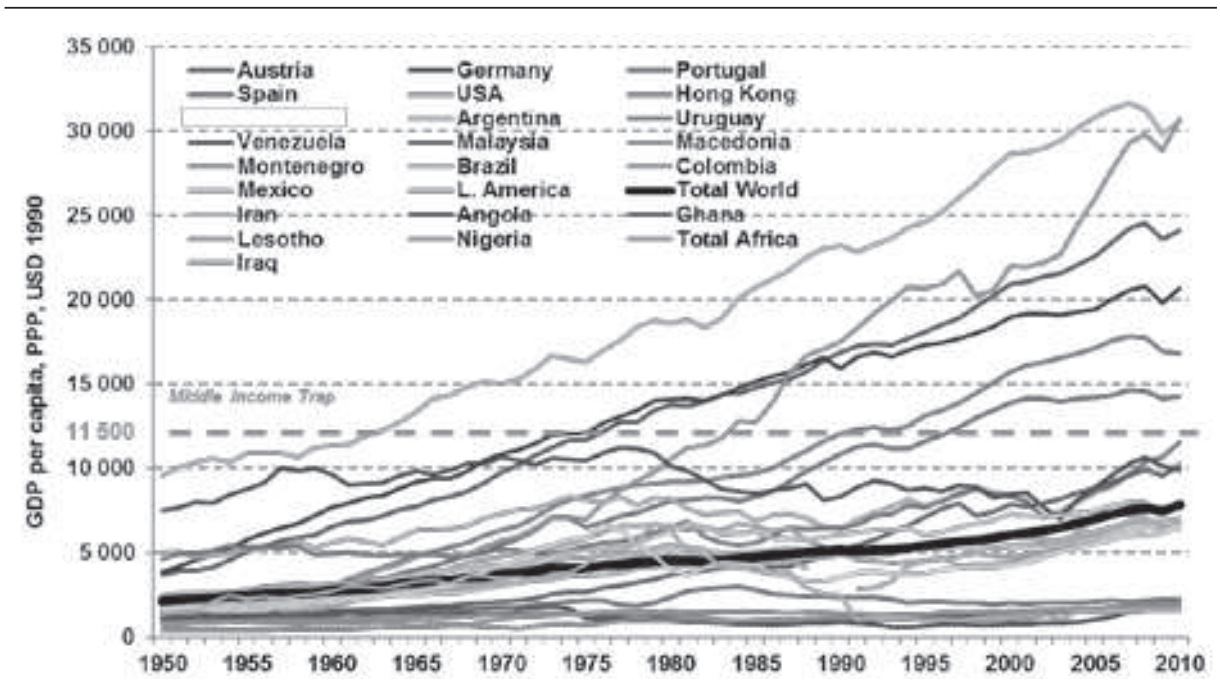

Figure 2. Middle income trap - interpretation by Felipe et al. (2012)

Source: own elaboration based on Maddison Project (Maddison Project Database, 2014).

It is important to notice that setting 'fixed' thresholds such as GDP per capita in USD might be problematic. One can argue that by following this approach in the long run, all countries will eventually escape the middle income trap. Agenor and Canuto (2012) from the World Bank understand middle income trap differently as they compare the level of economic development by GDP per capita relative to the USA GDP per capita. To the best of our knowledge, the United States of America is recognized by all papers which concentrate on the middle income trap as an example of a country that managed to avoid the trap. The USA is internationally recognized as a highly successful and innovative economy. Thus, it was selected as the benchmark for other countries in many articles - the World Bank article used by us being among them. Agenor and Canuto (2012) conclude that countries which fell into the middle income trap, were stuck between $5 \%$ and $45 \%$ of GDP per capita of the USA between 1960 and 2009. They argue that countries that fell into the trap had typically low level of human capital, low level of infrastructure development and their institutions were not well adequately designed nor were they based on good governance practices. Following the examples of Eichengreen at al. (2012), Ayiar et al. (2013) and Felipe et al. (2012), they suggest that what increases the chances of avoiding the trap are: productivity and innovation growth. 


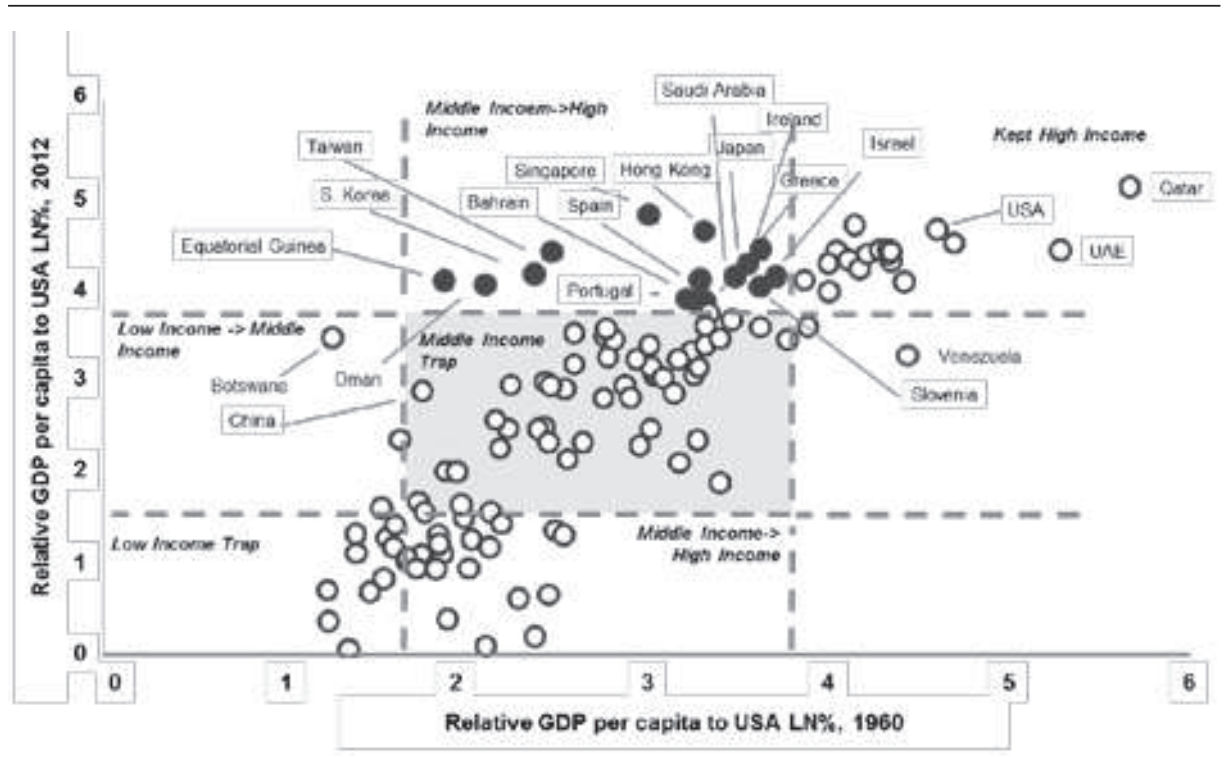

Figure 3. Middle income trap - interpretation by Agenor and Canuto

Source: own elaboration based on Maddison Project (Maddison Project Database, 2014).

The last piece of research presented in our paper is a Polish report published by the Institute for Structural Research. Bukowski, Szpor and Śniegocki (2012) argue that the middle income threshold is at the level between $45 \%$ and $65 \%$ of GDP per capita of the USA. They suggest that excessive regulation, high share of public sector in the economy and dependency on cheap labor increase the risk of falling into the trap. Again, the Polish analysts follow the previously mentioned international researchers and emphasize the important role that productivity and innovation play in avoiding the middle income trap. 


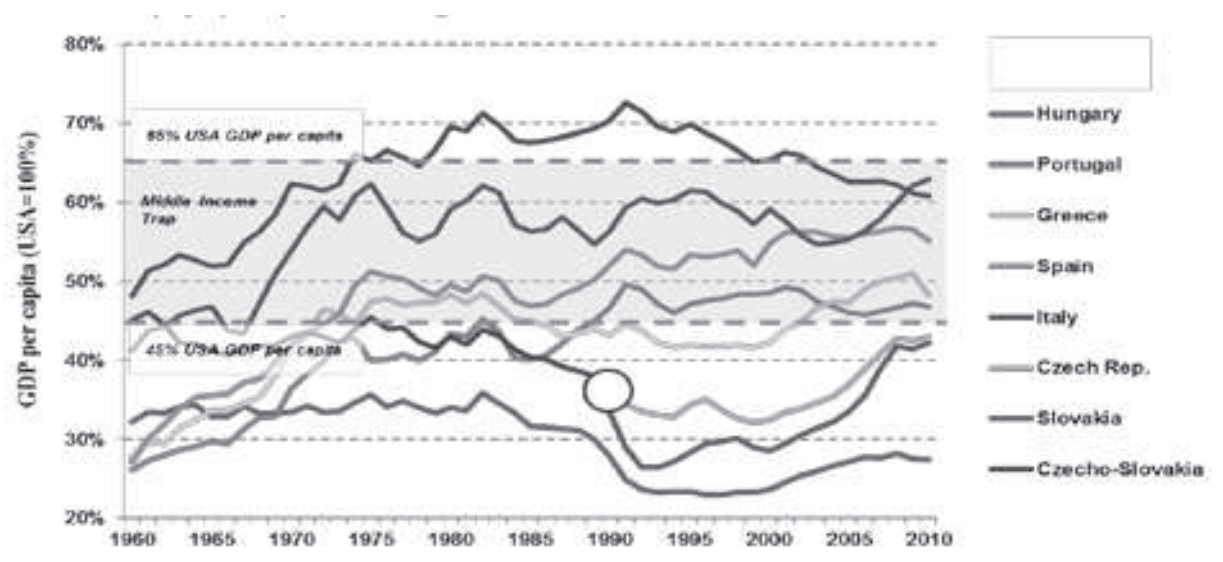

Figure 4. Middle income trap - interpretation by Bukowski et al. (2012)

Source: own elaboration based on Maddison Project (Maddison Project Database, 2014).

As discussed above, there are many ways economists understand "where" the middle income trap is, in terms of the thresholds. However, there are relevant common grounds. The first of them is the basic understanding that a middle income trap occurs when a country 'used up' its initial, primitive sources of growth. The second element is the fact that all of the papers suggested that low level of innovativeness of the economy increases the probability of falling into the trap. Of course, there are exceptions. Most noticeable are the resource-rich countries that managed to avoid the trap without much effort put into increasing innovativeness or productivity. However, as pointed out by Brahmbhatt, Canuta and Vostroknutova (2010), those countries in most cases risk falling into another 'trap' called the 'Dutch disease'. The World Bank economists argue that as resource rich countries become more and more dependable on the extraction of natural resources, their economies go through structural changes that are expected to include contraction or stagnation of other tradable sectors of the economy (in most cases manufacturing), accompanied by an appreciation of the country's real exchange rate. In the long run, these countries will have to deal with high wage expectations and low levels of competitiveness. Eventually, they might see their economic growth slow down as well and will face similar challenges as other middle income trap countries. Thus, a follow up question appears: what public polices make it possible for countries to transform economies into more innovation driven ones? 


\section{SUCCESSFUL PUBLIC POLICIES AIMED AT INCREASING INNOVATION}

As previously noted, we will concentrate on the examples of Finland, Israel and the USA. Their economies belong to different economic areas and have various cultural foundations. Economists such as: Eichengreenet et al. (2012), Agenorl and Canuto (2012), Felipe et al. (2012), Bukowski et al. (2012) and Ayiar et al. (2013) agree that these countries managed to escape the trap thanks to one common feature - by initiating a well-designed economic strategy they preserved the growth of innovativeness and transformed from importers into exporters of innovations. It was this innovative growth that resulted in the increases in productivity, allowed these countries to maintain their high rates of economic growth, and eventually allowed them to avoid the middle income trap. It is important however to notice that all three examples provided in the paper face significant economic problems nowadays. Nevertheless, in this section we aim to investigate what historical triggers helped these countries transform from low to highly innovative economies, disregarding their present economic challenges.

The support for innovations is a central part of strategies for Finland, Israel and the USA. The proposal that the state may effectively stimulate innovative development by means of appropriate economic policies was analyzed, among others, by Breznitz and Zimmermann (2008). They suggest that the advances of management science make it possible to design economic policies that will effectively promote innovative growth. However, they note that the essence of effective interventions lies in creation of appropriate environment for the development of innovation and a relevant system of stimuli. The state support is especially needed in the first stage of the development of innovations. Contrary to common beliefs, Venture Capital (VC) funds are not strongly involved in supporting the research and development stage. Studies conducted by Mazzucato (2013), Breznitz (2007), Breznitz and Zimmermann (2008) and Breznitz and Ornston (2013) suggest that even these high-risk VC funds decide mostly to get involved in a particular investment when they can see a product prototype that has already undergone tests and the trial period. This, however, requires financial expenditure and an initial investor who accepts the fact that the research may never generate results that could be commercialized. Therefore, the state can act as a very important player at the very beginning of the cycle of innovation development. Of course, there are examples of private investors being successful at this stage as well. However, in most cases, private actors tend to be risk-averse, which justifies public interventions.

Scientific research shows that such public interventions are effectively made via specialized state institutions (or public-private hybrids). For example,

Perspectives on Innovations Management - Environmental, Social and Public Sector Innovations, Krzysztof Klincewicz, Anna Ujwary-Gil (Eds.) 
Mazzucato (2013) points out that the work on a new drug may last more than 10 years, while the average life of a VC fund investment is only 3-5 years. The average time needed to develop a drug that could be marketed in the USA is 17 years, and the costs amount to 403 million dollars. Simultaneously, only 1 in 10,000 drugs is allowed to be marketed. That is why, according to Mazzucato's estimates (2013), 75\% of all new drugs in the USA have been developed as a result of research projects funded by the public National Institutes of Health.

The same author also indicates that the technological breakthroughs which led to the establishment of companies such as: Google, Apple or Microsoft, were also originally financed by the state. The search algorithm on which Google's success rests was financed by National Science Foundation Grant (NSF, 2013). In its initial development stage, Apple was also financed by public systems of innovation support, including the Small Business Innovation Research Program. Many major computer innovations can be attributed to the American Defense Advanced Research Project Agency (for example: the Internet, based on the ARPANET).

The key role of the state in the first stage of creating innovations and the importance of well-constructed institutions supporting the financing of primary research were also emphasized by Breznitz and Ornston (2013). They suggest that the transformation of Israel and Finland into countries whose growth became innovation-based, was caused by public interventions conducted by peripheral institutions that were delegated such tasks. In case of Finland it was Sitra - a state investment fund, established in 1967 as part of the Bank of Finland. It was this institution that financed investment in technological innovations in Finland. In Israel, a similar role was performed by the Office of the Chief Scientist, which financed investments in new technologies (Breznitz and Ornston, 2013). This was supported also by YOZMA - a publicly co-funded VC initiative, which played a key role in strengthening the innovativeness of the economy.

\section{POLAND AND THE MIDDLE INCOME TRAP}

In the first section of the paper, we reviewed five selected papers showing alternative interpretations of the middle income trap. These four papers provided three different thresholds for the middle income trap. All of them are once again presented below - however, this time only for the Polish economy.

Poland managed to avoid the trap according to the middle income trap interpretation presented by Eichengreen et al. (2012) and Ayiar et al. (2013). However, it still remains within the scope of the middle income trap according 
to Felipe et al. (2012), Agenor and Canuto (2012) and Bukowski et al. (2012). Thus, it is hard to decide whether Poland managed to avoid the trap or faces the danger of falling into it.

There is a growing consensus among economists that since the Polish economic growth is fueled by low labor costs and productivity achieved mainly through import of know-how and innovations from abroad, thus being similar to case to countries that were stuck in the middle income trap (as previously presented), there also is a significant risk of a substantial economic slowdown in the medium term (Bukowski, Halesiak and Petru, 2013; Geodecki, Hausner, Majchrowska, Marczewski, Piątkowski, Tchorek, Tomkiewicz and Weresa, 2013). While short-term economic growth forecasts for Poland are beneficial, long-term projections support the thesis that Poland might lose its dynamic momentum. According to foreign sources (such as the International Monetary Fund or World Bank) and domestic forecasts (such as the National Bank of Poland or Ministry of Finance), the economic growth in the next 3-5 years will reach around 3.0-3.5\% of GDP and be among the highest rates in the EU. Longterm forecasts, however, predict that Poland will stop bridging the gap which separates it from the most developed countries (as e.g. USA) around 2030. OECD analyses (2012) indicate that in the next 50 years, the Polish economy growth rate will be among the lowest ones in OECD countries. According to these institutions, within the next 15 years, Polish GDP per capita will grow at an average annual rate of $2.3 \%$. However, this growth will gradually slow down and from 2030 on, it will fall to a mediocre 1.1\% per year. According to OECD estimates, the highest wealth level per capita in Poland (compared to the US level) will be reached in 2030 (amounting to 55\% of USA GDP per capita) and since that moment, the distance will start to grow again (the wealth level will fall to $51 \%$ of USA GDP per capita in 2060). OECD suggests that Poland will not manage to catch up with Greece or Portugal. Significant decline of the economic growth rate in the future will result from the declining productivity growth rates in our economy and low levels of innovativeness - this is in line with analyses conducted by Polish economists as well (Bukowski et al. 2013, Hausner et al. 2013).

Perspectives on Innovations Management - Environmental, Social and Public Sector Innovations, Krzysztof Klincewicz, Anna Ujwary-Gil (Eds.) 


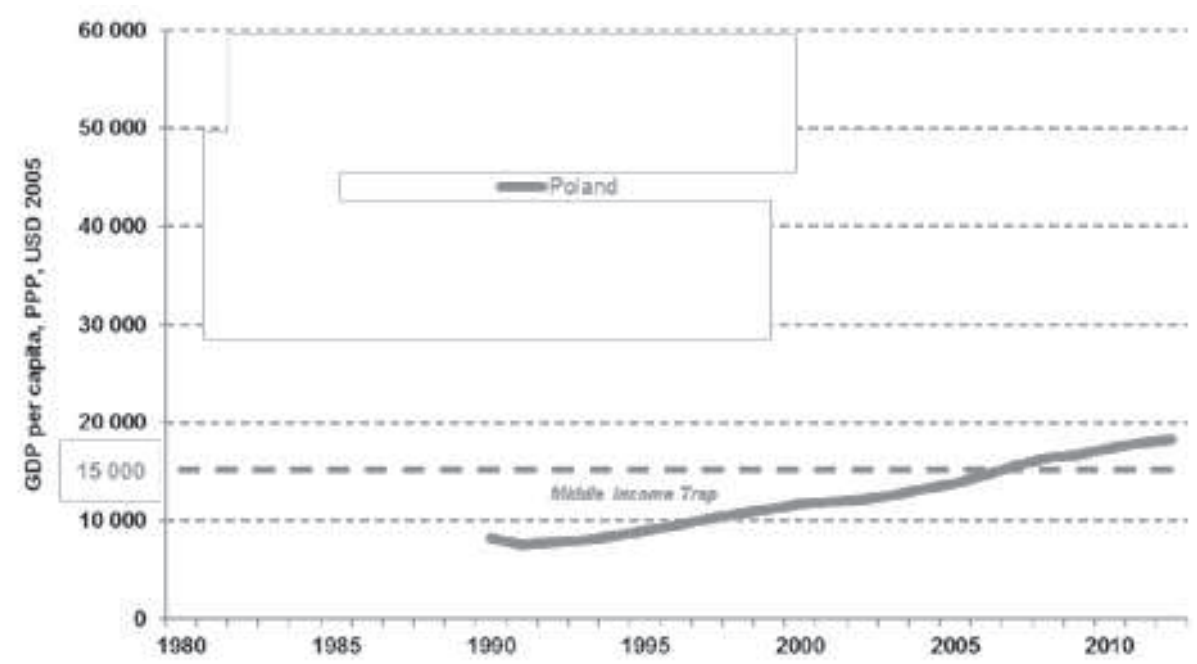

Figure 5. Middle income trap - interpretation by Eichengreen et al. (2012) and Ayiar et al. (2013)

Source: own elaboration based on World Development Indicators (World Bank, 2014).

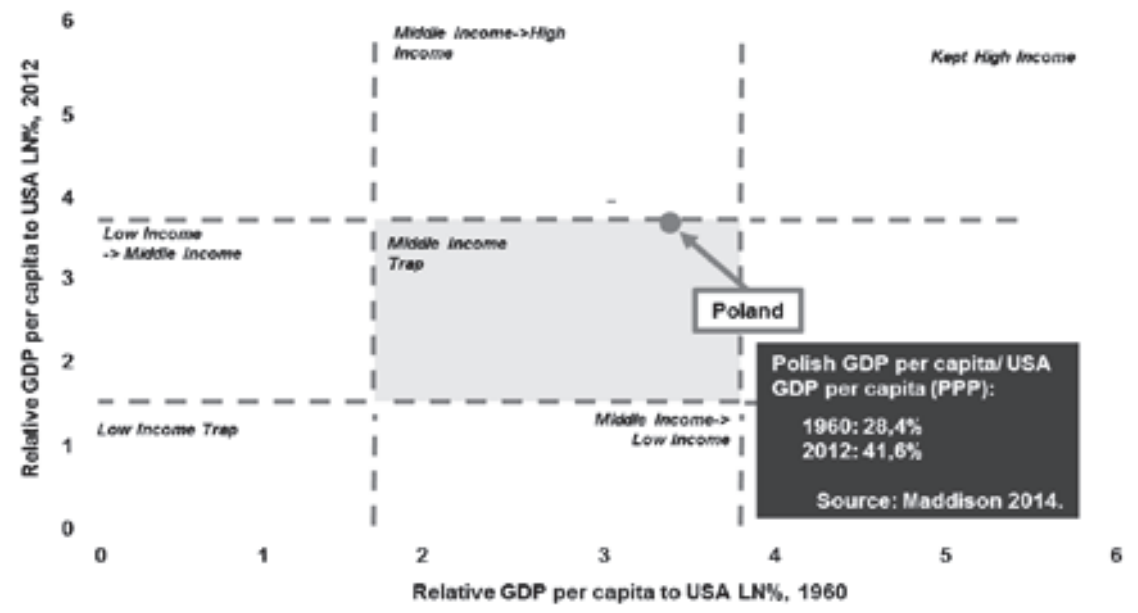

Figure 6. Middle income trap - interpretation by Agenor and Canuto (2012)

Source: own elaboration based on Maddison Project (Maddison Project Database, 2014). 


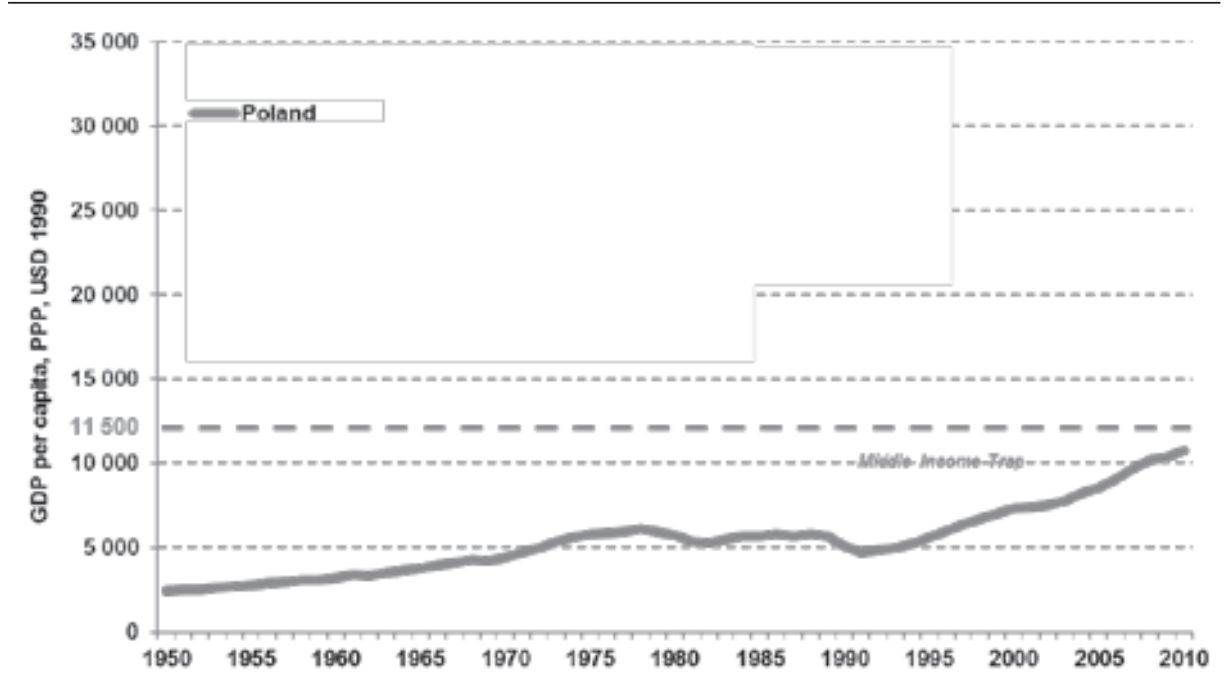

Figure 7. Middle income trap - interpretation by Felipe et al. (2012)

Source: own elaboration based on Maddison Project (Maddison Project Database, 2014).

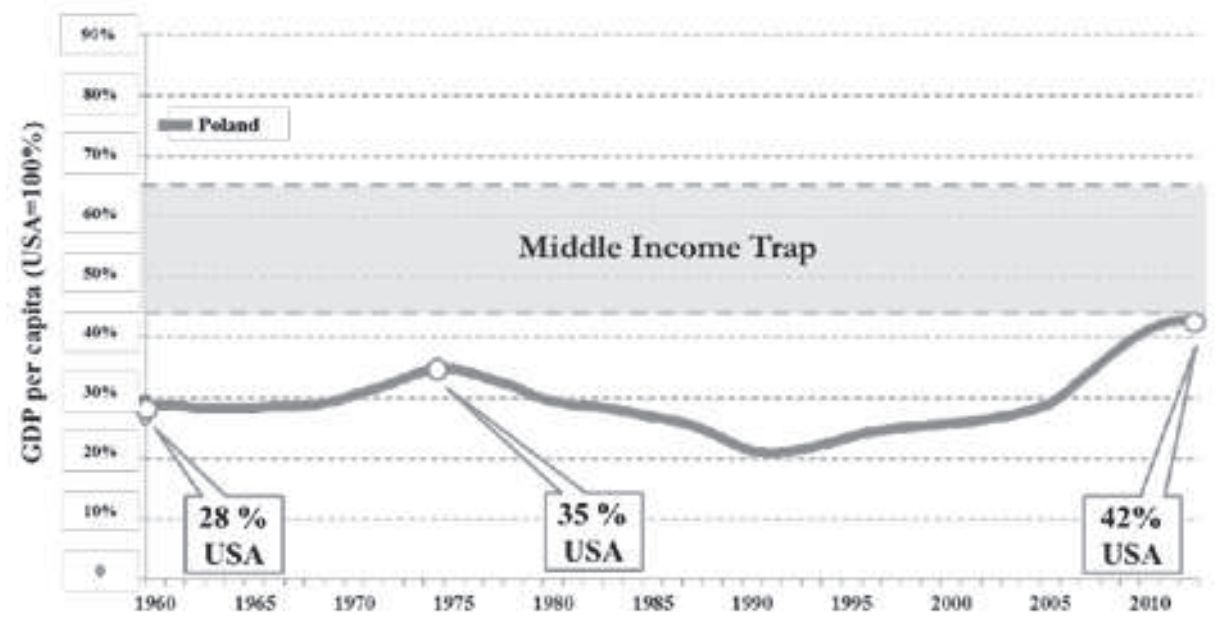

Figure 8. Middle income trap - interpretation by Bukowski et al. (2012) Source: own elaboration based on Maddison Project (Maddison Project Database, 2014).

In view of the rankings, statistical data and reports of international institutions, Poland's economy is not innovative. According to the World Economic Forum, Poland occupies the $23^{\text {rd }}$ position in the competitiveness ranking of 27 European Union countries. The innovative level and potential of our country $\left(22^{\text {nd }}\right.$ place in the EU), broadly understood business environment $\left(22^{\text {nd }}\right.$ position in the $\left.\mathrm{EU}\right)$ or application of digital technologies $\left(23^{\text {rd }}\right.$ position

Perspectives on Innovations Management - Environmental, Social and Public Sector Innovations, Krzysztof Klincewicz, Anna Ujwary-Gil (Eds.) 
in the EU) leave a lot to be desired. Another EU report (Regional Innovation Scoreboard 2012), reveals a very low evaluation of Polish innovative capabilities - we are the fourth least innovative country in the European Union. The most significant recommendations and comments concerning the low level of innovativeness in Poland are presented in the table below.

Table 1. Selected reports on economic innovativeness in Poland

\begin{tabular}{|c|c|}
\hline Ranking & Poland's position \\
\hline Bloomberg & $24 / 110$ \\
\hline $\begin{array}{l}\text { Bloomberg sees the main problems of } \\
\text { Poland in: low total expenditure on R\&D, low } \\
\text { productivity per employee (calculated as GDP } \\
\text { per employee), small number of professional } \\
\text { (including PhDs) involved in R\&D processes } \\
\text { per one million of population. }\end{array}$ & \\
\hline Global Innovation Index & $49 / 142$ \\
\hline $\begin{array}{l}\text { According to Global Innovation Index } \\
\text { ranking, Poland has the following problems: } \\
\text { total innovation performance (counted as } \\
\text { innovation influence on economic growth), } \\
\text { lack of company cooperation clusters, a small } \\
\text { number of new forms of activity among } \\
\text { population aged 15-64. }\end{array}$ & $\begin{array}{l}\text { Poland achieves a low score in Creativity } \\
\text { Output category. The factors that pull down } \\
\text { our score are: lack of ICT applications in } \\
\text { creating business and organizational models } \\
\text { or a large share of non-returnable assets in } \\
\text { companies. }\end{array}$ \\
\hline International I Index (BCG) & $52 / 110$ \\
\hline $\begin{array}{l}\text { In BCG ranking Polish innovation performance } \\
\text { does not look effective. The ranking takes } \\
\text { into account such indicators as: productivity } \\
\text { of innovative solutions (including patents, } \\
\text { technology transfers, R\&D efficiency). }\end{array}$ & $\begin{array}{l}\text { Poland also has low labor productivity and } \\
\text { shareholders' profits. Poland does not come } \\
\text { well in influence of innovation on company } \\
\text { migration and economic growth, either. }\end{array}$ \\
\hline World Economic Forum & $23 / 27$ \\
\hline $\begin{array}{l}\text { Poland has few patentapplications, companies } \\
\text { are less able to adopt new technologies, } \\
\text { access to them is the most difficult in the } \\
\text { whole EU. }\end{array}$ & $\begin{array}{l}\text { Poland should focus on improving the business } \\
\text { surroundings, for example by simplifying the } \\
\text { establishing and running of a company and } \\
\text { promoting digital technologies. }\end{array}$ \\
\hline Union Scoreboard 2014 & $25 / 28$ \\
\hline $\begin{array}{l}\text { In the EU scoreboard, Poland is presented } \\
\text { as "a moderate innovator". The authors } \\
\text { emphasize low investment in innovations. } \\
\text { This indicator has slightly improved since } \\
2006 \text {, but it has been deteriorating compared } \\
\text { to the EU, where it has been increasing much } \\
\text { faster. }\end{array}$ & $\begin{array}{l}\text { Most indicators of the EU index are below } \\
\text { the European average, the worst of them } \\
\text { being: a small number of PhDs from outside } \\
\text { the EU, a small number of patent applications } \\
\text { concerning social challenges and low incomes } \\
\text { from Polish licenses and patents abroad. }\end{array}$ \\
\hline
\end{tabular}

Source: based on: Innovation Union Scoreboard, 2014, Global Competitiveness Report, 2014, International I BCG Index (2014), Bloomberg Innovation Index (2014).

\section{CONCLUSION}

The aim of this paper was to verify whether Poland managed to avoid or still might fall into the middle income trap. In order to answer that question we started with a literature review concerning the notion of middle income 
trap. We presented five articles on this subject. We concluded the section by stating that there is no universal definition of the middle income trap. However, there are some common grounds among researches with regards to this phenomenon. Those include (but are not limited to) the basic understanding that middle income trap occurs when countries 'used up' their primitive growth engines (such as cheap labor for instance). As a result, they get 'stuck' between richer countries that compete using their innovations and poorer countries that compete by means of low prices. All of the cited studies agree that countries which managed to avoid the trap, increased the levels of innovativeness of their economies. In the next part we tried then to understand what public policies might be responsible for improving innovations. Literature suggests that countries such as the USA, Finland or Israel transformed their economies into innovation driven thanks to (but not limited to) top-down strategies, which were carried out by specialist public agencies. The literature also suggests that the state can act as a particularly important player in supporting innovation in the early stage of its development. This is the most risky phase of the development of innovation which requires (typically) not only substantial financial investments but also a long time horizon which in most cases can be discouraging for private investors. In the last part we tried to determine whether Poland managed to avoid falling into the middle income trap in accordance with various definitions of the trap. We came to a conclusion that while there is no clear answer to that question, Polish economy show signs that it might have difficulties keeping up the impressive pace of catching up with high-income countries. This is due to the limitations of primitive growth engines such as low-cost labor and productivity increases achieved through imports of know-how and innovations, which have fuelled the Polish growth so far. At the same time, as Poland - according to international rankings - is not a highly innovative country, there are substantial risks of a significant slowdown of economic growth in the medium and long term.

\section{References}

Agenor, P., Canuto, O. (2012). Middle Income Growth Traps. Washington: World Bank.

Aiyar, M.S., Duval, M.R.A., Puy, M.D., Wu, M.Y. \& Zhang, M.L. (2013). Growth slowdowns and the middle-income trap. International Monetary Fund Working Paper No. WP/13/71. Retrieved from: http://www. longmeizhang.com/wp1371.pdf.

Brahmbhatt, M., Canuto, O. \& Vostroknutova, E. (2010). Dealing with Dutch Disease. The World Bank. Retrieved from: http://hdl.handle. net/10986/10174.

Perspectives on Innovations Management - Environmental, Social and Public Sector Innovations, Krzysztof Klincewicz, Anna Ujwary-Gil (Eds.) 
Breznitz, D. \& Zimmermann, C. (2008). The State as Strategic Manager? Challenge, 51(4), 70-88.

Breznitz, D. (2007). Innovation and the State-Development Strategies for High Technology Industries in a World of Fragmented Production: Israel, Ireland, and Taiwan. Enterprise and Society, 7(4), 675-685.

Breznitz, D. \& Ornston, D. (2013). The Revolutionary Power of Peripheral Agencies Explaining Radical Policy Innovation in Finland and Israel. Comparative Political Studies, 46(10), 1219-1245.

Bukowski, M., Halesiak, A. \& Petru, R. (2013). Konkurencyjna Polska 2020. Deregulacja i Innowacyjność. Warszawski Instytut Studiów Ekonomicznych. Retrieved from: http://www.wise-institute.org.pl/ common/files_download.php?fid=17.

Bukowski, M., Halesiak, A. \& Petru, R. (2013). 25+. Od podwykonawcy do kreatora, czyli jak zapewnić Polsce kolejne 25 lat sukcesu. Warszawski Instytut Studiów Ekonomicznych. Retrieved from: http://tep.org.pl/wpcontent/plugins/download-monitor/download.php?id=176.

Bukowski, M., Szpor, A., Śniegocki, A. (2012). Drzemiq̨y tygrys spętany orzet. Dylematy polskiej debaty o polityce inwestycyjnej. Instytut Badań Strukturalnych. Retrieved from: http://ibs.org.pl/files/ibs_wp3_ ekoinnowacje_120912_2.pdf.

Eichengreen, B., Park, D. \& Shin, K. (2012). When Fast-Growing Economies Slow Down: International Evidence and Implications for China. Asian Economic Papers, 11(1), 42-87.

Eichengreen, B., Park, D. \& Shin, K. (2013). Growth slowdowns redux: New evidence on the middle-income trap. National Bureau of Economic Research. NBER Paper No. 18673. Retrieved from: www.nber.org/ papers/w18673.

Felipe, J., Abdon, A. \& Kumar, U. (2012). Tracking the Middle-Income Trap: What is it, Who is in it, and Why? Levy Economics Institute, Working Paper, No. 715. Retrieved from: www.levyinstitute.org/pubs/wp_715. pdf.

Gill, I.S., Kharas, H.J. \& Bhattasali, D. (2007). An East Asian renaissance: ideas for economic growth. World Bank Publications. Retrieved from: http:// siteresources.worldbank.org/INTEASTASIAPACIFIC/Resources/2262621158536715202/EA_Renaissance_full.pdf.

Gill, I.S. \& Raiser, M. (2012). Golden growth: Restoring the lustre of the European economic model. World Bank Publications. Retrieved from: http://documents.worldbank.org/curated/en/2012/04/16234385/ golden-growth-restoring-lustre-european-economic-model.

Geodecki, T., Hausner, J., Majchrowska, A., Marczewski, K., Piątkowski, M., Tchorek, G., Tomkiewicz J. \& Weresa, M. (2013). Jak awansować w światowej lidze gospodarczej. Kraków: Fundacja Gospodarki i Administracji Publicznej. Retrieved from: http://fundacja.e-gap.pl/ dokumenty/raporty/Konkurencyjna_Polska_Raport_2013.pdf. 
Mazzucato, M. (2000). Firm Size, Innovation, and Market Structure: The Evolution of Industry Concentration and Instability. Cheltenham, UK Northampton, MA: Edward Elgar Publishing.

Mazzucato, M. (2011). The entrepreneurial state. Soundings, 49, 131-142.

Mazzucato, M. (2013). Financing innovation: creative destruction vs. destructive creation. Industrial and Corporate Change, 22(4), 851-867.

Orłowski, W. (2012). Stan i perspektywy polskiej gospodarki na tle globalnego kryzysu. PriceWaterhouseCoopers. Retrieved from: www.paiz.gov.pl/ files/?id_plik=16977.

Piatkowski, M. (2013). Poland's new golden age: shifting from Europe's periphery to its center. The World Bank Paper No. 6639. Retrieved from: http://www-wds.worldbank.org/external/default/WDSContentServer/ WDSP/IB/2013/10/04/000158349_20131004093542/Rendered/PDF/ WPS6639.pdf.

Winiecki, J. (2012). Transformacja postkomunistyczna. Studium przypadku zmian instytucjonalnych. Warszawa: C.H. Beck.

\begin{abstract}
Abstrakt (in Polish)
Celem naszej pracy była zweryfikowanie czy Polska zdołała uniknqć czy też wciqż może wpaść w pułapkę średniego dochodu. Artykuł omawia literaturę dotyczqca pułapki średniego dochodu. Chociaż istniejq rozbieżne interpretacje pojęcia pułapki średniego dochodu, ekonomiści doszli do wspólnych wniosków podkreślajqcych znaczenie transformacji ekonomii opartej na innowacjach jako metody uniknięcia pułapki. W dalszej części naszej pracy przedstawiamy przegląd polityki publicznej wspierajqcej te niezmiernie potrzebne transformacje. Dochodzimy do wniosku, iż państwa takie jak Finlandia, Izrael czy USA wprowadziły dobrze zaprojektowane, odgórne strategie ekonomiczne, promujqce rozwój innowacji i powołały skutecznie działajqce agencje zajmujqce się wdrażaniem innowacji. Wyjqtek stanowiq tutaj państwa dysponujqce bogatymi zasobami, którym udało się uniknqć pułapki średniego dochodu bez wdrażania takich działań, jednak w większości przypadków państwa takie staja $w$ obliczu zagrożenia znalezienia się w innej pułapce, zwanej "chorobq holenderskq". $W$ dalszej części artykułu próbujemy zastosować koncepcję pułapki średniego dochodu wobec Polski i dochodzimy do wniosku, iż nie da się jednoznacznie określić czy Polsce udało się uniknqć tej pułapki czy też nie. Następnie dokonujemy przeglqadu najpowszechniejszych przeszkód dla innowacyjności w Polsce. Obecne źródła wzrostu mogq okazać się niewystarczajqce by zapewnić wzrost gospodarczy pozwalajqcy nam dogonić najbardziej rozwinięte państwa.
\end{abstract}

Kluczowe słowa: innowacja, gospodarka, strategia, kapitał społeczny, instytucje, kapitał ludzki, infrastruktura, pułapka średniego dochodu.

Perspectives on Innovations Management - Environmental, Social and Public Sector Innovations, Krzysztof Klincewicz, Anna Ujwary-Gil (Eds.) 


\section{Biographical notes}

Kamil Pruchnik is a doctoral candidate at the Warsaw School of Economics. Currently, he works at the National Bank of Poland, where he conducts research on middle income traps. Most recently, he has worked at the World Bank at the Office of the Chief Economist for Europe and Central Asia, where he contributed to the report: "Diversified Development", which concentrated on the Dutch disease. He was also a member of the Polish Delegation to the UN in 2014 where he worked on the III Committee. Kamil is also involved in civic movements; he is a Research Fellow at the Civic Development Forum in Poland. Additionally, he has designed, developed and implemented a game that uses LEGO bricks to teach economics - Brickonomics. The project won the World Bank's Youth Innovation Fund award in 2013. He is also a cofounder of a Youth Reforming Poland movement, which gathered a team of over 40 young economists to design a new public policy strategies which would enable Poland to avoid the middle income trap.

Jerzy Toborowicz is a doctoral student at the Kozminski University, preparing a research project on behavioral public policy. He currently works at the World Bank, where he is doing research on Polish public system of supporting the innovations and discovering the firms' needs. Additionally, he has codesigned, co-developed and implemented a game that uses LEGO bricks to teach economics - Brickonomics. The project won the World Bank's Youth Innovation Fund in 2013. He is also a co-founder of a Youth Reforming Poland movement, which gathered a team of over 40 young economists to design a new public policy strategies which would enable Poland to avoid the middle income trap. 